\title{
Instructional Media for Construction Drawing by Autodesk Revit Structure
}

\author{
Jaturawit Sirimaha*, Panyakit Kaewlex \\ Department of Civil Engineering \\ Rajamangala University of Technology Thanyaburi \\ Pathum Thani, Thailand \\ *Jaturawit_s@rmutt.ac.th
}

\begin{abstract}
The purpose of this research is to create a teaching tool using Autodesk Revit program. The production of instructional media for drawing construction with the Autodesk Revit Structure consists of the study of data and usage of program procedures. The teaching material of Autodesk Revit Structure was produced in form of video media. The instructional media was assessed by the experts. The students also evaluate the satisfaction and then bring evaluation results are evaluated by dividing the assessment into two types is content and technical production of the media. After that, the results from the validation of the content of the teaching media was used to improve the media of Autodesk Revit Structure according to the recommendations of the experts. The instructional media was used to test with a sample of students via pretest and posttest. The test result is in a good level. From the results of the assessment and achievement tests effective teaching of drawing materials, with the Autodesk Revit Structure program can be used in teaching and learning.
\end{abstract}

Keywords- construction drawings, instructional media, Autodesk Revit Structure

\section{INTRODUCTION}

Drawing is a way of transferring the ideas of designers on paper for people to understand. Drawing also is one of the languages used in industrial work and a language that conveys the ideas or needs of the designer to others to know and understand correctly. However, in order to get a consistent understanding, drawing must be in a universal language. The symbols and various forms must be easy to understand, even those who do not study drawing are able to understand reasonably.

Autodesk Revit is an architectural design program with BIM (Building Information Modeling) [1]. Building modeling technologist, architectures, engineers, contractors or other relevant parties can use the detailed building information continuously to reduce duplication of work, conflicts, and cost of operating the whole system. At the same time, the quality of design works is improved. In building Information Modeling (BIM) for architecture, the architect is the creator of information to those involved in the design. The construction can be used smoothly [2]. Time was saved for creating new information over and over again. It can reduce construction costs and a chance of mistake. Revit Structure program designed for engineers. Building structure and especially engineering drawing can also be transferred to the analysis program and computed in different structural design programs.

Therefore, in order to learn drawing of a $3 \mathrm{D}$ construction model effectively, instructional media should be used [3]. The researcher has chosen the Autodesk Revit Structural Analysis Professional program which is a highly efficient software to draw the building construction.

\section{EXPERIMENTAL PROGRAM}

The process of the use of Autodesk Revit Structure software was determined by dividing into six chapters as follows: Chapter 1 Format and Functionality of Autodesk Revit Structure; Chapter 2 Constructing the Building; Chapter 3 Roof Structure Drawing; Chapter 4 Inserting reinforcing bars in structures; Chapter 5 Structural Materials Estimation; Chapter 6 Printing.

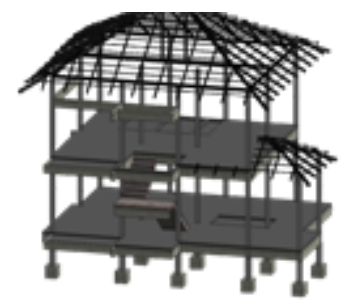

Fig. 1. 3D structure model

Instructional materials for Autodesk Revit Structure program in the format of video media was produced. Subsequently, the effectiveness of the instructional media, content was evaluated by experts and then applied to the sample to assess media performance [4]. 


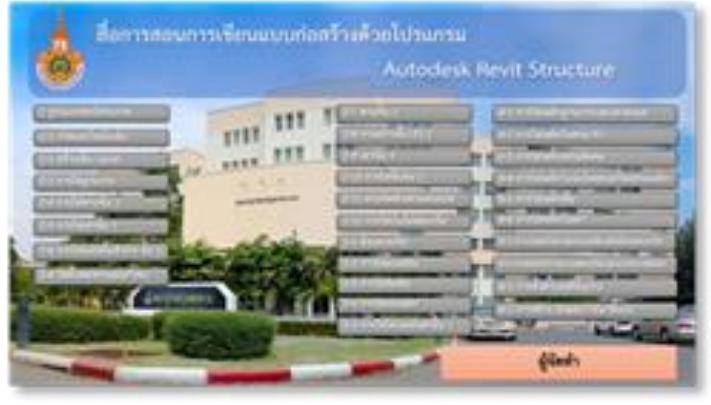

Fig. 2. Instructional media example.

The samples were used to evaluate the efficiency of instructional media [5]. The pre-test and the post-study tests were implemented to measure the effectiveness of the media. A satisfaction assessment, production techniques and content were conducted.

\section{TEST RESULTS AND DISCUSSIONS}

Implementation of project instruction video construction drawing, with the program of Autodesk Revit Structure by evaluating the efficiency of teaching materials in production techniques. There are six experts to evaluate. The criteria for interpreting the mean analyzes of the data shown in Table 1.

TABLE I. INTERPRETATION CRITERIA, MEAN MEAN LEVEL OF OPINION OF VIDEO MEDIA

\begin{tabular}{|l|l|}
\hline \multicolumn{1}{|c|}{ Mean } & \multicolumn{1}{c|}{ Comment level } \\
\hline $4.21-5.00$ & Very good \\
\hline $3.41-4.20$ & good \\
\hline $2.61-3.40$ & moderate \\
\hline $1.81-2.60$ & Fair \\
\hline $1.00-1.80$ & Should improve \\
\hline
\end{tabular}

Then, the evaluation results were used to find the mean which was summarized as shown in Table 2.

TABLE II. Shows The Mean Results of ANALysis of Production TECHNICAL DATA

\begin{tabular}{|l|l|l|}
\hline \multicolumn{1}{|c|}{ list } & $\bar{x}$ & \multicolumn{1}{|c|}{$\begin{array}{c}\text { Performance } \\
\text { feedback level }\end{array}$} \\
\hline Visual technique & 4.64 & Very good \\
\hline 1. Suitability meets content. & 4.71 & Very good \\
\hline 2. Clarity of illustrations. & 4.67 & Very good \\
\hline 3. Image size in presentation. & 4.79 & Very good \\
\hline $\begin{array}{l}\text { 4. The relationship between picture and } \\
\text { sound. }\end{array}$ & 4.50 & Very good \\
\hline Sound technique & 4.57 & Very good \\
\hline 5. Appropriateness of voice narration. & 4.43 & good \\
\hline 6. Clarity, sound accuracy. & 4.71 & Very good \\
\hline 7. The rhythm of reading aloud. & 4.50 & Very good \\
\hline $\begin{array}{l}\text { 8. Language or words that are easy to } \\
\text { understand. }\end{array}$ & 4.64 & Very good \\
\hline 9. Proper reading patterns. & 4.50 & Very good \\
\hline Alphabet technique & \\
\hline 10. Scale and read clarity. & \\
\hline $\begin{array}{l}\text { 11. Highlighting messages and key } \\
\text { points. }\end{array}$ &
\end{tabular}

Assessing the satisfaction of the teaching material content sample of 21 people evaluated. Then the evaluation results were used to find the mean which is summarized as in Table 3.

TABLE III. SHOWS ThE MEAN CONTENT SATISFACTION ANALYSIS AND THE RESUlts of THE ANALYSIS OF PRODUCTION TECHNICAL DATA

\begin{tabular}{|l|l|l|}
\hline \multicolumn{1}{|c|}{ list } & $\overline{\boldsymbol{x}}$ & \multicolumn{1}{|c|}{$\begin{array}{c}\text { Performance feedback } \\
\text { level }\end{array}$} \\
\hline Visual technique & 4.33 & Very good \\
\hline 1. Suitability meets content. & 4.00 & good \\
\hline 2. Clarity of illustrations. & 4.33 & Very good \\
\hline 3. Image size in presentation. & 4.00 & good \\
\hline $\begin{array}{l}\text { 4. The relationship between } \\
\text { picture and sound. }\end{array}$ & 4.00 & good \\
\hline Sound technique & 4.00 & good \\
\hline $\begin{array}{l}\text { 5. Appropriateness of voice } \\
\text { narration. }\end{array}$ & 3.33 & moderate \\
\hline 6. Clarity, sound accuracy. & 4.00 & good \\
\hline 7. The rhythm of reading aloud. & \\
\hline $\begin{array}{l}\text { 8. Language or words that are } \\
\text { easy to understand. }\end{array}$ & 4.00 & good \\
\hline 9. Proper reading patterns. & 4.33 & good \\
\hline Alphabet technique & 3.66 & good \\
\hline 10. Scale and read clarity. & \\
\hline $\begin{array}{l}\text { 11. Highlighting messages and } \\
\text { key points. }\end{array}$
\end{tabular}

Pre- and post-test of experimental group sample of 32 students were tested by taking 20 multiple-choice tests before and after class [6]. Then compare the results of the study test before and after studying with construction drawings using the Autodesk Revit Structure program as shown in Table 4.

TABLE IV. COMPARISON OF PRE- AND POST-STUdy TEST RESUlts, VIDEO TEACHING DRAWING CONSTRUCTION WITH THE AUTODESK REVIT STRUCTURE PROGRAM BEFORE AND AFTER STUDY OF THE CONTROL GROUP OF EXPERIMENTAL WITH 32 STUDENTS

\begin{tabular}{|l|l|l|l|l|l|}
\hline & n & mean & S.D & t & Sig. \\
\hline Pre test & 32 & 8.38 & 3.024 & -11.636 & 0.00 \\
\hline Post test & 32 & 13.72 & 3.082 & & \\
\hline
\end{tabular}

Then considering the difference between the pre-learning average with the teaching material for drawing construction using the Autodesk Revit Structure program and the postlearning average with the teaching material sweeping the construction with the Autodesk Revit Structure program, it was found that There was a statistically significant difference $(\mathrm{t}=$ $11.636, \mathrm{p}=0.00)$.

\section{CONCLUSIONS}

When finished teaching materials After that, the finished teaching materials were taken to 6 experts for evaluation, consisting of 3 media production and 3 content, and the results of the expert evaluation were divided into 2 areas: Production, media and content The results of the expert's assessment have opinions on media production, divided into 3 techniques as follows: 1) Visual technique. There is a good average. 2) Sound techniques. The average is at a good level. 3) Techniques of characters. There is a good average. And the 
results of the expert assessment have opinions on the content. There is a good average. Then, the results obtained from checking the correctness of the content of the teaching materials using the Autodesk Revit Structure program were adjusted according to expert recommendations. Then, the teaching material for using the Autodesk Revit Structure 2019 program was used for 31 students, a sample of the students who tested their knowledge before learning had an average of 4.43 points, and the post-study results had an average of 6.93 points. The sample was assessed the satisfaction of media production, divided into 3 techniques as follows: 1) Visual technique. There is a very good average. 2) Sound techniques. The average is at a very good level. 3) Techniques of characters. There is a very good average and content satisfaction. There is a very good average. Sample test results.

The results showed that the score after training was significantly higher than the pre-training score at 0.05 .

Therefore, it can be concluded that the efficiency of teaching materials for using the Autodesk Revit Structure program can be used for teaching and learning in 3D computer construction writing, as well as in 3D modeling. In the building structures are different as well.

\section{RECOMMENDATION}

- Those who are interested can develop and use with other subjects or the contents of this project can be further modified.

- A computer running Autodesk Revit should be reasonably efficient. This will help to use it smoothly.

\section{REFERENCES}

[1] K. Limpongsathorn, Comparison of two-dimensional programming and simulation methods. Building information (BIM) is used in building drawings for retail stores in Thailand. Master of Engineering Thesis in Engineering Management Siam University, 2017.

[2] Suphawut, Integration of java-based BIM with spatial database International Journal of Civil Engineering, 2010.

[3] P.D. Widyastuti, M. Mardiyana, and D.R.S. Saputro, “An Instructional Media using Comics on the Systems of Linear Equation," In J. Phys. Conf. Ser (Vol. 895, p. 012039). September, 2017.

[4] Linear Equation, "International Conference on Mathematics and Science Education (ICMScE)

[5] S. Chaicharoen, "(Media)." [Online]. Accessible from: https://www.classstart.org/classes/297?fbclid=IwAR12QOxNTDbImb1x GJIDSCKdQZqo2n6Mxg84jXaZToLfYB5HG9ViyEqqyjg (Date of retrieval: 12 January 2020), 2002.

[6] A. Anukulvej, Development of a technical practice teaching model on the Internet for vocational students. Doctor of Education Thesis Educational Technology Branch, Srinakharinwirot University, 2008. 